\title{
ULOGA KNJIŽNICE U BIBLIOTERAPIJI (S OSVRTOM NA SVEUČILIŠNE KNJIŽNICE)
}

\author{
THE ROLE OF LIBRARIES IN BIBLIOTHERAPY \\ (WITH REFERENCE TO UNIVERSITY LIBRARIES)
}

\author{
Zorica Antulov \\ Sveučilišna knjižnica \\ Sveučilište u Zadru \\ zantulov@unizd.hr
}

UDK / UDC 027.7 057.875: [028.8:615.85]

Pregledni rad / Review paper

Primljeno / Received: 18. 6. 2018

Prihvaćeno / Accepted: 7. 12. 2018.

\section{Sažetak}

Cilj. Liječenje knjigom (biblioterapija) najčešće se povezuje s područjem psihijatrije, gdje se provodi kao pomoćna i kreativna terapijska metoda. Cilj je ovog rada razmotriti u kolikoj je mjeri smisleno provoditi biblioterapiju u knjižnici kao jednoj od onih ustanova gdje se ona provodi kao preventivna metoda na zdravoj populaciji. Propituje se i mogućnost te smislenost njezina provođenja u sveučilišnim knjižnicama koje su po tom pitanju u našoj zemlji često nepravedno zapostavljene.

Metoda. U radu se razmatraju različite vrste biblioterapije te se ističe razvojna biblioterapija kao oblik koji bi se mogao i trebao provoditi u knjižnicama. Problematizira se uloga knjižničara u provođenju biblioterapije, sloboda njegova djelovanja i njegova kompetentnost. Rezultati istraživanja provedenih izvan Hrvatske koji su prikazani u ovom radu govore o stupnju važnosti njezina provođenja u sveučilišnim knjižnicama među studentskom populacijom. Rad se zasniva na metodi analize postojećih spoznaja te njihova sintetiziranja u novom tekstu.

Rezultati. Smatra se da uvođenjem biblioterapije u knjižnice one dobivaju još jednu društveno korisnu ulogu te da se pritom ne treba zadržavati isključivo na školskim i

Vjesnik bibliotekara Hrvatske 62, 1(2019), 151-165

ISSN 0507-1925

(C) VBH 2018. 
narodnim knjižnicama, već da i sveučilišna knjižnica, koja se obraća studentima kao posebno osjetljivoj skupini mladih ljudi, može dati svoj doprinos na tom području.

Originalnost / vrijednost. Humanost biblioterapije i poticanje njezina provođenja u knjižnicama te propitkivanje mogućnosti koje po tom pitanju mogu pružiti sveučilišne knjižnice čine vrijednost ovog rada.

Ključne riječi: biblioterapija, knjižnice, sveučilišne knjižnice, studenti

\begin{abstract}
Purpose. Book treatment or bibliotherapy is most commonly associated with the psychiatric field, where it is performed as an auxiliary and creative therapeutic method. The aim of this paper is to consider how meaningful it is to have bibliotherapy in a library as one of the institutions where it is implemented as a preventative method and carried out on healthy population. There is also the question of the possibility of its implementation in university libraries that are often unfairly neglected on this matter in Croatia.
\end{abstract}

Approach. The paper considers different types of bibliotherapy, emphasizing the developmental bibliotherapy as a form that could and should be implemented in libraries. The role of librarians in the implementation of bibliotherapy, freedom of action and competence is being problematized. The results of the research conducted outside of Croatia, presented in this paper, indicate the degree of importance of its implementation in university libraries among the student population. The paper is based on the method of analysing and reviewing the existing knowledge and literature and their synthesis in the new text.

Results. It is believed that by introducing bibliotherapy in libraries they are gaining one more, socially useful role, which should not be carried out solely in school and public libraries, but also in university libraries, which, addressing students as a particularly vulnerable group of young people, can give their own contribution to this area.

Originality / value. The humanity of bibliotherapy and the encouragement of its implementation in libraries and the questioning of opportunities that the university libraries can provide, are the dominant values of this work.

Keywords: academic libraries, bibliotherapy, libraries, students 


\section{Uvod}

Ako s jedne strane postavimo pojam liječenje ili terapija, a s druge pojam knjiga, učinit će nam se da se radi o oprečnim pojmovima koji nemaju ništa zajedničko. Ipak, često smo se nalazili u situaciji da tijekom ili nakon čitanja knjige imamo potrebu pričati o njoj i osjećajima koje je u nama izazvala. Prepoznavši tu osobitost knjige, psiholozi ju počinju koristiti kao pomoćno sredstvo prilikom terapija. Na taj način ta dva pojma postaju smisleno spojena u vidu biblioterapije kao terapijskog postupka, u početku rezerviranog isključivo za psihologiju i medicinu. Međutim uskoro i neke druge struke prepoznaju svoje mogućnosti u tom području te pojam prestaje biti vezan isključivo uz kliničko okružje. Jedna je od takvih struka knjižnična znanost.

U dugotrajnom druženju s knjigom knjižničari s njom ostvaruju jedinstven odnos. Poznavanje knjiga i korisnika omogućuje im da, ukoliko postoji dobra organizacija i poznavanje postupka biblioterapije, postanu jedna od vodećih struka u tom području. Međutim ovdje treba istaknuti da među različitim vrstama knjižnica postoje značajne razlike u stupnju provođenja biblioterapije i zainteresiranosti za nju. Kad govorimo o knjižnicama i poticanju na čitanje, o čitateljskim klubovima, čitateljskim navikama i drugim društveno usmjerenim aktivnostima koje se poput biblioterapije vežu uz knjigu i čitanje, uglavnom pomišljamo na narodne ili pak školske knjižnice. Neosporno je da one mogu na tom polju dati izrazito velik doprinos, no ne treba zanemariti ni mogući doprinos nekih drugih vrsta knjižnica koje se, na putu otvaranja prema svojoj novoj, višestrukoj ulozi, mogu iskazati i na tom području. Među tim knjižnicama treba istaknuti sveučilišne koje, slično kao i školske, imaju za svoje korisnike uglavnom mlade ljude suočene s brojnim problemima koje donosi odrastanje, odvajanje od obitelji, zahtjevan studijski program i sl. Kad je riječ o biblioterapiji, na tu se vrstu knjižnica manje pomišlja, ali postoji mogućnost da će u budućnosti biti prepoznata upravo njihova sposobnost da i u tom području daju izniman i sebi svojstven doprinos.

\section{Biblioterapija}

\subsection{Kratka povijest „liječenja knjigom“}

Na jednom egipatskom papirusu od prije 3600 godina piše:

„Ljepša je knjiga negoli ponosna palača negoli zapad, gdje grob se do groba niže; ljepša negoli što je utvrđen dvorac, negoli spomenik što se u hramu diže. “1

1 Kulundžić, Z. Put do knjige. Zagreb: Epoha, 1959. Str. 9. 
Ljepota i vrijednost knjige bila je prepoznata još od davnina, među drevnim narodima, u starim civilizacijama. No nije bila cijenjena samo zbog svoje ljepote već joj se u prošlosti nerijetko pripisivalo i božansko porijeklo. Tako se u Babilonu izum pisma pripisuje bogovima Oanesu i Nabu, u Egiptu bogu Totu, u Perziji su ljudi dobili pismo od boga posredstvom proroka Zaratustre, a Svarun je u slavenskoj mitologiji ostavljao ljudima poruke urezujući ih u koru drveta. ${ }^{2}$ Božansko podrijetlo knjige uvjetovalo je i njezine čudesne moći, kako na ovom tako i na drugom svijetu. O tome nam svjedoči i Egipatska knjiga mrtvih (zbirka svetih izreka koje se pokapaju s mrtvacem). Naime smatralo se da je nakon smrti duša pokojnika putovala podzemnim svijetom gdje je nailazila na mnoge prepreke i opasnosti. Zato se pored njegova sarkofaga stavljala kopija Knjige mrtvih. Sve nevolje na svom posljednjem putovanju pokojnik je mogao nadvladati molitvama i čarolijama zapisanim u njoj. $^{3}$

I dok je na onom svijetu knjiga pomagala pokojniku u snalaženju u tajnama i nevoljama koje ga snađu u zagrobnom životu, na ovom je svijetu osobito bila cijenjena ljekovita moć svete knjige. Svete knjige ili knjige koje su pisali sveci mogle su, prema vjerovanju vjernika, liječiti ili štititi od bolesti. ${ }^{4}$ Egipćani, Židovi, Rimljani i mnogi drugi stari narodi vjerovali su u moći svetih knjiga. One su mogle podariti plodnost, obraniti od zlih sila, mogle su vraćati vid slijepima, sluh gluhima te zacjeljivati rane. Kod kršćana će se takva vjerovanja osobito raširiti u srednjem vijeku, a smatralo se da su osobito ljekovite one knjige koje su pisane izravno od Boga ili svetaca. Jedan od takvih primjera je Lukino Evanđelje. Vjerovalo se da će bolesnik ozdraviti od svih bolesti ako ga samo dotakne. ${ }^{5} \mathrm{Da}$ bi se zaštitili od bolesti, uroka i svih đavolskih nakana te kao zalog životne sreće, ljudi su uz tijelo nosili svete formule, magijske i slične zapise, ali i cijele knjige u umanjenom formatu (Biblija, Kuran ili neka druga sveta knjiga). Takvi su se zapisi (knjige) zvali amuleti ili talismani, a najčešće su se nosili ovješeni oko vrata ili ušiveni unutar odjeće. Običaj njihova nošenja povezuje se s prastarim vjerovanjima kojima se svete knjige identificiraju sa samim Bogom te stoga i njegovim čudotvornim moćima. ${ }^{6}$

Danas više ne nosimo knjigu oko vrata zbog vjerovanja u njezinu čudesnu moć izlječenja na isti način na koji se to činilo i vjerovalo nekad. No i danas, kad ju nosimo pod rukom ili u torbi, na laptopu, mobitelu ili nekom drugom elektroničkom čitaču, moramo joj priznati određena ljekovita svojstva. Naravno, ne u onom drevnom, čudotvornom smislu, ali činjenica je da knjiga često može pomoći čovjeku da pomogne sebi samom.

\footnotetext{
2 Usp. isto, str. 216-233.

3 Usp. Massey, G. Egipatska knjiga mrtvih. [citirano: 2018-11-22] Dostupno na: http://nikolavujic.weebly.com/uploads/3/4/8/0/3480733/gerald_massey_-_egipatska_knjiga_mrtvih.pdf.

${ }^{4}$ Usp. Stipčević, A. Sudbina knjige. Lokve: Naklada Benja, 2000. Str. 41.

5 Usp. isto, str. 43.

6 Usp. isto, str. 47.
} 


\subsection{Liječenje knjigom u današnje doba: definicija pojma biblioterapija}

Kad danas govorimo o ljekovitim svojstvima knjige, nerijetko se susrećemo $\mathrm{s}$ izrazom biblioterapija. Pojam je sastavljen od riječi biblio u značenju knjiga i therapeia u značenju liječenje. U stručnu literaturu uvodi ga S. Crothers 1916. godine. Pod tim terminom on poima postupke temeljene na čitanju u svrhu poboljšanja zdravlja. Pojam biblioterapija često se veže uz medicinsko okružje, a za to je velikim dijelom zaslužan drugi sastavni dio izraza: terapija. Prema definiciji koju navodi Websterov rječnik iz 1961. godine, a koji biblioterapiju definira kao

„uporabu odabranih knjiga i književnoga gradiva kao terapeutskih pomagala u medicini i psihoterapiji, pa i kao rješavanje osobnih problema vođenim/usmjerenim čitanjem"“7,

već se pomalo nazire odvajanje biblioterapije od medicine.

Prema T. Reščič-Rihar i J. Urbaniji biblioterapija ne liječi, već pomaže pojedincu pojasniti gubljenje značenja te, iz spomenutog razloga, ne može biti vezana uz medicinu. ${ }^{8}$ Prema tome, ona se može provoditi i na zdravoj populaciji u svrhu poboljšavanja kvalitete života. Kroz postupak biblioterapije dolazi do interakcije između čitatelja i književnog lika, a unutar toga dolazi i do boljeg razumijevanja osobnih emocija. Razumijevanjem vlastitih emocija lakše ćemo prevladavati one koje su negativne ili ćemo se barem naučiti lakše „nositi s njima“. ${ }^{9}$

Cilj je biblioterapije pomoću književnog djela osvijestiti zatomljene, neverbalizirane i neosviještene emocije, a prema J. Rudež to se zbiva kroz procese identifikacije, projekcije, katarze i uvida.

a) Identifikacija - Nakon što smo problem identificirali, lakše ga prihvaćamo te se (suočeni s njime i činjenicom da nismo sami te da i drugi ljudi također proživljavaju iste probleme, patnje, sumnje i strahove) lakše nosimo s njime.

a) Projekcija - Ukoliko problemu pristupamo s gledišta zamišljenih likova, ako ga projiciramo na druge osobe, smanjujemo bojazan izlaganja sebe samih pred drugima. Možemo ga shvatiti i kao prebacivanje krivnje.

b) Katarza - Emocionalno uzbuđenje do kojeg dolazi nakon čitanja književnog djela dovodi do oslobađanja napetosti kod čitatelja. Prema Aristotelu ona predstavlja pročišćavanje emocionalne svjesnosti o vlastitim

\footnotetext{
7 Reščič-Rihar, T.; J. Urbanija. Biblioterapija. Ljubljana: Filozofska fakulteta, Oddelek za bibliotekarstvo, 1999. Citirano prema: Mikuletič, N. Biblioterapija u školskoj knjižnici ili razgovor o knjizi. // Vjesnik bibliotekara Hrvatske 53, 2(2010), str. 136.

8 Usp. Isto. Citirano prema: Mikuletič, N. Nav. dj., str. 137.

9 Usp. Janavičiene D. Bibliotherapy process and type analysis: review of posibilities to use it in the library. // Tiltai 4(2010), str. 120. [citirano 2018-11-12]. Dostupno na: http://eds.a.ebscohost. $\mathrm{com} / \mathrm{eds} / \mathrm{pdfviewer} / \mathrm{pdfviewer}$ vid=6\&sid=2653a38d-6ed8-4838-9c14-5532ea97f6a7\%40sessionmgr4008.
} 
motivima $\mathrm{i}$ iskustvima, a prema stupnju značajnosti koji biblioterapija ima za korisnika to je najbitniji sastavni dio tretmana.

c) Uvid: Uvidom u vlastite reakcije na probleme iznesene u tekstu čitatelj može bolje osvijestiti svoje probleme, kao i načine kojima ih može prevladati. ${ }^{10}$

Očekivane promjene osobnosti koje sudionik doživljava po posljednjoj fazi biblioterapijskog procesa mogu rezultirati promjenama u stavovima, a konačno i promjenom u ponašanju. ${ }^{11}$

Činjenica je da knjige obiluju životnim iskustvom, mudrošću koja nam može poslužiti kao pomoć u trenucima kad nam ponestane osobne životne mudrosti. Obiluju situacijama koje možemo primijeniti na svoj život, događajima kakvi se događaju i nama, a s kojima se nije lako suočiti i o njima progovoriti. U njima nerijetko nailazimo i na likove s kojima se možemo poistovjetiti. Ponekad nam nude moguća rješenja problema, ponekad osjećaj da nismo sami i da se stvari možda i ne mogu uvijek promijeniti, ali da se često mogu prihvatiti tako da se iz njih uzme ono najbolje radi poboljšavanja kvalitete života. Stoga biblioterapija možda i nije klasično liječenje, ali određeni stupanj ljekovitosti ne može joj se poreći. No da bi bila učinkovita, trebaju je provoditi osobe koje poznaju i knjige i ljude, odnosno način na koji ljudi doživljavaju pojedine knjige: emocije i opći ton kojim određena knjiga odiše. Ukoliko ju provode nestručne osobe, može biti neučinkovita ili čak proizvesti suprotan učinak.

\section{Biblioterapija u knjižnicama}

\subsection{Zastupljenost $i$ vrste biblioterapije}

Nad ulazom u starogrčku knjižnicu u Tebi stajao je natpis koji ju je definirao kao mjesto za ozdravljenje duša. Ako knjiga zaista može biti lijek za dušu, nameće se pomisao da bi i knjižnica, kao mjesto na kojem se ona pronalazi i čuva, mogla biti svojevrsno lječilište, da bi se u njoj mogla provoditi biblioterapija te da bi knjižničar mogao postati osoba kompetentna za njezino provođenje.

Činjenica je da se biblioterapija sve češće prakticira u različitim profesijama. Tako je prema M. Forestu stanje njezine zastupljenosti prema profesijama za 1998. godinu izgledalo ovako: predvodnici u bili psiholozi (57\%), potom su slijedili knjižničari $(20 \%)$, medicinsko osoblje $(11 \%)$ i socijalni radnici $(10 \%) .{ }^{12}$

10 Usp. Rudež, J. Bibliografska metodologija. // Hrvatski 2, 1-2(2004), str. 56-66.

11 Usp. Krpan, K.; I. Klak Mršić; V. Cej. Primjena razvojne biblioterapije u radu s djecom i mladima u narodnoj knjižnici. // Vjesnik bibliotekara Hrvatske 61, 1(2018), str. 353.

12 Usp. Forrest, M. Recent development in reading therapy: a rewiew of the literature. // Health Library Review 15, 3(1998). Citirano prema: Riahinia, N.; A. Asemi. Librarians' participation in 
Iz prethodno navedene podjele prema zastupljenosti u profesijama vidimo da knjižničari tu vrlo visoko kotiraju. Zauzimaju drugo mjesto, odmah iza psihologa, što je velik uspjeh ako uzmemo u obzir da je knjižničarstvo struka koja je dovodila u pitanje vlastitu kompetentnost za to područje. Glavni uzrok problema po pitanju osposobljenosti knjižničara za provođenje biblioterapije sadržan je u drugom dijelu izraza: terapija. Naime sama riječ terapija asocira na kliničko okruženje i dovodi pojam u vezu s medicinom. S druge strane, činjenica je da knjižničari, kao poznavatelji literature, imaju prednost u odabiranju literature koja se koristi u biblioterapijske svrhe te da im to omogućuje povlašten položaj za sudjelovanje i suradnju sa psiholozima ili (ukoliko su dobro upoznati s postupkom) samostalno provođenje biblioterapije.

Stupanj udjela knjižničara u provođenju biblioterapije umnogome će ovisiti o vrsti biblioterapije.

Prema T. Reščič-Rihar u osnovne vrste biblioterapije ubrajaju se institucionalna, klinička i razvojna biblioterapija. Institucionalnu su biblioterapiju provodili liječnici na hospitaliziranim pacijentima u bolnicama. Knjižničar je pritom mogao biti tek suradnik, ne i osoba određena za njezino provođenje. Za razliku od institucionalne biblioterapije, stupanj udjela knjižničara povećava se kod provođenja kliničke biblioterapije. Naime kod te vrste biblioterapije, namijenjene osobama $\mathrm{s}$ emocionalnim smetnjama i poremećajima u ponašanju, potrebno je zajedničko sudjelovanje liječnika i knjižničara. Za razliku od te dvije vrste biblioterapije, namijenjene osobama koje imaju određenih zdravstvenih, emocionalnih ili problema u ponašanju, razvojna je biblioterapija namijenjena zdravim pojedincima u svrhu očuvanja duševnog zdravlja te normalnog osobnog i tjelesnog razvoja. Podjednako ju može izvoditi socijalni radnik, učitelj i knjižničar. ${ }^{13}$

Prema svemu opisanom lako možemo razumjeti da potpunu slobodu djelovanja knjižničar ima u posljednjoj vrsti biblioterapije, razvojnoj biblioterapiji, gdje može dati i najveći doprinos. Biblioterapija kakva se provodi u knjižnicama jest ona koja se provodi na zdravim pojedincima u svrhu očuvanja i poboljšanja zdravlja te lakšeg suočavanja i prevladavanja raznih životnih problema.

\subsection{Odabir literature}

Kao što je već istaknuto, knjižničar kao osoba koja poznaje knjige, a ukoliko je educiran i u području samog biblioterapijskog postupka, može biti i prava osoba za njegovo provođenje. Kao što D. Škrbina ističe, biblioterapija će biti uspješna

bibliotherapy treatment of distressed students. // Interdisciplinary Journal of Contemporary Research in Business 3, 6(2011), str. 710.

13 Usp. Reščič-Rihar, T.; J. Urbanija, Nav. dj. Citirano prema: Mikuletič, N. Nav. dj., str. 137. 
jedino izborom ,prave knjige, u pravo vrijeme za pravi problem“14, što znači da uz samo poznavanje literature postoje i određene stavke kojima se u njezinu odabiru treba voditi, a o kojima će u daljnjem tekstu biti riječ. Budući da su ljudi individualna bića, nerijetko se događa da vrlo različito reagiraju na isti tekst, različito ga interpretiraju i doživljavaju, što je rezultat osobnih razlika među čitateljima. Međutim bez obzira na osobne različitosti postoje neke univerzalne stavke kojima se vodimo pri odabiru literature. Istraživanja pokazuju da knjige u kojima se javlja osjećaj beznađa, stalna sjeta, nasilje i tragičnost nisu preporučljive za biblioterapijski tretman. ${ }^{15}$ Govoreći o poetoterapiji, I. Bašić ističe neke osnovne odrednice u odabiru literature:

1. Preporuča se odabiranje univerzalnog materijala radi moguće identifikacije. Temeljna emocija pritom mora biti ona koja je najbliža raspoloženju grupe. Ipak, ako je temeljna emocija depresija, da bi bila od pomoći, mora u sebi sadržavati osjećaj nade i optimizma.

2. Treba izbjegavati materijale koji su konfuzni, beznadni i depresivni te ne pružaju mogućnost suočavanja s negativnim osjećajima i stanjima.

3. Metafore u pjesmi trebaju biti građene konzistentno i dosljedno (to vodi ka čistom, kohezivnom mišljenju).

4. Treba izbjegavati materijal koji hrani negativne emocije poput veličanja ubojstva, samoubojstva i sl. ${ }^{16}$

Budući da se u knjižnicama biblioterapija najčešće provodi u grupi, treba voditi računa i o dobi, spolu, podrijetlu, obrazovanju, društvenom statusu i drugim čimbenicima koji čine čitateljski obzor. Iz tih se razloga biblioterapija provodi kroz djelovanje tzv. biblioterapijskih timova koji obuhvaćaju određenu populacijsku strukturu: primjerice rad s djecom rastavljenih roditelja, ovisnicima o drogi, alkoholu i sl. ${ }^{17}$ Kao konkretan primjer odabira literature za pomoć djeci rastavljenih roditelja preporuča se priča o Pepeljuzi ${ }^{18}$, a $\mathrm{J}$. Rudež daje zanimljiv primjer odabira literature za britanske vojnike u bolnicama i na ratištima nakon Prvoga i

14 Škrbina, D. Art terapija i kreativnost. Zagreb: Veble commerce, 2013. Str. 226,

15 Usp. Raguotiene, G. Atversta knyga. Vilinus, 2008. Citirano prema: Indrasiene, V.; E. Kapočiute. Usage of bibliotherapy elements when solving adolescent socio-pedagogical problems. // Socialinis Ugdymas 18, 7 (2009), str. 90. [citirano: 2018-22-11]. Dostupno na: http://eds.a.ebscohost.com/eds/pdfviewer/pdfviewer?vid=13\&sid=2653a38d-6ed8-4838-9c14-5532ea97f6a7\%40sessionmgr4008.

16 Usp. Bašić, I. Biblioterapija i poetska terapija: priručnik za početnike. Zagreb: Balans centar, 2011. Str. 48-49.

17 Usp. Šurlan, D. Biblioterapija. // Godišnjak knjižničarskog društva Sisačko-moslavačke županije 2(2008), str. 13.

18 Usp. Fanner, D; C. Urquhart. Bibliotherapy for mental health service users Part 1: A systematic review. // Health Information \& Libraries Journal 25, 4(2008). Citirano prema: Riahinia, N.; A. Asemi. Nav. dj., str.711. 
Drugog svjetskog rata: njima su se, prema njihovoj želji, slali ratni romani i knjige o nacionalnoj povijesti, a ne popularna književnost, kriminalistički romani i slična literatura za koju bismo mogli pomisliti da bi im bila interesantna. ${ }^{19}$ Prema J. Rudež svaki čitatelj na određeni način postaje suautor književnog teksta. ${ }^{20}$ On sam bira i na svoj način tumači ono što je u tekstu dano u naznakama, što se možda samo naslućuje. Tako se potiče čitateljeva mašta i oboružava ga se za stvarni život. Iz svega se može zaključiti da treba poštovati i grupna, ali i osobna obilježja svakog sudionika biblioterapijskog tretmana te da je uvijek moguće naići na određene otklone od uobičajenih reakcija i poimanja.

\subsection{Način provođenja}

Uz poznavanje literature i valjan odabir one koja odgovara određenom problemu, knjižničar mora biti upućen i u sam postupak provođenja biblioterapije.

Slijedeći spoznaje brojnih autora koji su se bavili pitanjem provođenja biblioterapije, D. Janavičiene navodi mogućnost izbora sljedećeg redoslijeda postupaka:

1. identifikacija problema

1. kvalitetan odabir teksta

2. čitanje teksta

3. razgovor $\mathrm{i} /$ ili druge kreativne tehnike (interpretacija, crtanje, slušanje glazbe itd.)

4. ispravak ili nadopunjavanje popisa literature koju je moguće koristiti za određeni problem. ${ }^{21}$

Prvi korak, identifikacija, nužan je da bismo uopće otkrili razloge provođenja biblioterapije (prepoznajemo problem). Pritom treba utvrditi i intelektualna, obrazovna i druga obilježja te interese osoba na kojima se biblioterapija provodi, što je nužno znati da bismo uopće mogli pristupiti drugoj fazi: odabiru teksta. Nakon te faze, o kojoj je već bilo riječi i u kojoj knjižničar doista može pokazati svoju kompetenciju, slijedi faza čitanja teksta. Biblioterapija traži način čitanja koji izaziva empatiju s osjećajima likova, književno djelo čini bližim i toplijim te omogućuje iskustvo katarze.

Sljedeća faza, faza dijaloga ili drugih kreativnih tehnika, smatra se izuzetno važnom fazom biblioterapijske metode. Psihijatar J. Sučylaite smatra da se tek kroz dijalog među ljudima mogu otkriti pravi razmjeri (granice) određenog patološkog stanja te da se upravo u toj fazi biblioterapijskog postupka otkrivaju stvarni

19 Usp. Rudež, J. Biblioterapija. // Hrvatski 3, 1-2(2005), str. 110-111.

20 Usp. isto. Str. 124.

21 Usp. Janavičiene, D. Nav. dj., str. 125. 
razmjeri problema zbog kojeg se biblioterapija i provodi. ${ }^{22}$ Od osobite je važnosti osigurati ohrabrujuće i toplo okružje u kojem će se sudionici moći „otvoriti“ i progovoriti o stvarima koje ih tište. Ponekad se umjesto dijaloga koriste druge kreativne tehnike koje ljudima pomažu da ,progovore“ o problemu, a da se pritom ne izlažu izravno pred drugima. Naime mnogim je ljudima teško govoriti o svojim osjećajima, boje se da će biti ismijani ili su jednostavno sramežljivi. Neke od takvih tehnika koje zamjenjuju dijalog jesu: crtanje (npr. crtež koji prikazuje vlastite osjećaje), pisanje (npr. pisanje pisma junaku djela), glumačko izvođenje i sl. Takve metode smatraju se ravnopravnima dijalogu. Tako se npr. smatra da igranjem uloga u dramskom procesu možemo povećati prilagodljivost vlastitih životnih uloga i postati svjesniji sebe, svojih veza s obitelji, prijateljima, kao i vlastitom prošlošću, a da pisanje može imati ispovjednu vrijednost te razotkriti „tajne“ koje nas tište te tako omogućiti i učinak katarze. ${ }^{23}$

Posljednja faza biblioterapijskog postupka ujedno je i faza započinjanja novog ciklusa. Svejedno provodi li se s novom grupom ili pak sa starom, u biblioterapiji kao cikličkom, a ne linearnom postupku, korekcije su nužne. ${ }^{24} \mathrm{U}$ toj se, posljednjoj, fazi na temelju prethodnog iskustva i povratne informacije koju dobivamo od primatelja biblioterapije otkriva koje su knjige bile od pomoći za određenu vrstu problema i na koji način. Na temelju toga omogućuje se kvalitetnije korištenje istih knjiga ili odabir novih, za koje se pretpostavlja da bi za određeni problem mogle biti učinkovite. Na samom kraju biblioterapijskog postupka vraćamo se dakle opet knjižničaru kao osobi koja završava i omogućuje započinjanje novog biblioterapijskog ciklusa svojim neosporivim kompetencijama u odabiru literature.

\subsection{Biblioterapija u sveučilišnoj knjižnici}

U svojoj definiciji mladenaštva N. Mikuletič navodi da je mladenaštvo: „,...razdoblje između djetinjstva i odrasle dobi i traje približno jedno desetljeće, od jedanaeste ili dvanaeste godine do početka ranih dvadesetih godina. U tom razdoblju mladi doživljavaju značajne tjelesne, spoznajne i psihosocijalne promjene. Njihov brz tjelesni rast utječe na njihovu duhovnost što se izražava kroz velike emocionalne promjene." ${ }^{\text {"25 }}$

Iz definicije je očito da se radi o osjetljivom životnom razdoblju te je jasno da je često teško nositi se s promjenama koje ono donosi i da mladi ljudi nerijetko imaju potrebu progovoriti o njima.

22 Usp. Sučylaite, J. Interakcine biblioterapija medicinoje. // Gydymo menas 1(2004). Citirano prema: Janavičiene D. Nav. dj, str. 128.

${ }^{23}$ Usp. Rudež, J. Bibliografska. Nav. dj., str. 57-60.

24 Usp. Janavičiene, D. Nav. dj., str. 129.

25 Mikuletič, N. Nav. dj., str. 135. 
Posebna skupina mladih ljudi jesu studenti. Nastavak školovanja i visoki zahtjevi obrazovnog sustava, uz sve probleme koji i inače prate mladenačku dob, stavljaju pred tu skupinu ljudi nove izazove, ali uz njih i nova opterećenja koja povremeno rezultiraju stresom. Najčešći problemi koji izazivaju stres kod studenata jesu problemi kod učenja i ispitna groznica, financijski problemi, kao i problemi u međusobnim odnosima. ${ }^{26}$ Osim toga, mnogi studenti odlaskom na studij napuštaju rodno mjesto, a ponekad i državu. Udaljenost od kuće i novo kulturno okruženje dovode do kulturnog šoka, što često rezultira strahom, anksioznošću i nemogućnošću kvalitetne interpersonalne komunikacije te u studenata stvara svojevrsni stres.

Tako npr. izvještaj American College Health Association iz 2008. godine kazuje da je $13 \%$ studenata imalo simptome anksioznosti, $18 \%$ simptome depresije, $43 \%$ povremene simptome depresije, a čak njih $10 \%$ ozbiljno je razmišljalo o samoubojstvu. ${ }^{27}$ Suvremene se knjižnice nerijetko smatraju dnevnim boravkom zajednice kojoj služe te, uz dom i posao kao prva dva važna mjesta u životu svakog čovjeka, njezinim trećim mjestom ${ }^{28}$, a to je slučaj i sa sveučilišnim knjižnicama. Studenti u njima provode dobar dio svog obrazovnog, ali i slobodnog vremena. Postavlja se pitanje može li biblioterapija barem donekle pomoći toj skupini ljudi da se lakše suoče s teškoćama i prevladaju probleme koje im donosi to životno doba, kao i može li sveučilišna knjižnica, kao njihovo „treće“, odnosno vrlo blisko mjesto, pritom imati značajnu ulogu.

Istraživanje o kojem u svom članku govore N. Riahinia i A. Asemi ${ }^{29}$, provedeno na skupini od 40 iranskih studenata (koji osobno smatraju da su pod edukacijskim stresom), ukazuje na vidnu promjenu razine stresa kod studenata prije i nakon provođenja biblioterapijskog postupka. Za mjerenje razine stresa koristila se subskala depresije DASS (Depresion, Anxiety and Stress Scale) prema kojoj je razina stresa prikazana u tri sloja: od 0 do 14 - niska razina stresa; od 15 do 28 umjerena razina; od 29 do 42 - visoka razina stresa.

Studenti su bili podijeljeni u tri grupe:

1. grupa od 13 studenata u kojoj biblioterapiju provode dva knjižničara (biblioterapijska grupa)

1. grupa od 14 studenata u kojoj psiholog provodi individualni biblioterapijski tretman, tzv. biblioterapijske konzultacije (konzultacijska grupa)

2. kontrolna grupa od 13 studenata.

\footnotetext{
26 Usp. Riahinia, N.; A. Asemi. Nav. dj., str. 712.

27 Usp. Muto, T.; S. C. Hayes; T. Jeffcoat. The effectiveness of acceptance and commitment therapy bibliotherapy for enhancing the psychological health of Japanese college students living abroad. // Behavior Therapy 42(2011), str. 331. DOI 10.1016/j.beth.2010.08.009.

${ }^{28}$ Usp. Velagić, Z. Povijesnost koncepcije knjižničnog trećeg prostora. // Narodne knjižnice kao treći prostor: zbornik radova / 9. savjetovanje za narodne knjižnice u Republici Hrvatskoj; uredile Dunja Marija Gabriel i Jelica Leščić. Zagreb: Nacionalna i sveučilišna knjižnica, 2015. Str. 30.

29 Usp. Riahinia, N.; A. Asemi. Nav. dj.
} 
U biblioterapijskoj grupi kao literatura je odabran tekst The Majid stories. Majid je i sam student koji nailazi na niz životnih problema, a rješava ih na zanimljiv i simpatičan način, ponekad doduše smiješan, ali uvijek efektivan. Postupak se provodio u 8 sesija. U svakoj sesiji (dijelu) knjižničar najprije čita tekst, a potom slijedi 5-10 minuta rasprave o Majidovim problemima i rješenjima koja je pronašao. Za razliku od biblioterapije koja se provodila u grupi i provodili su ju knjižničari, konzultacijska biblioterapija provodila se individualno u posebnoj sobi i provodio ju je psiholog. U obje skupine (biblioterapijska grupna terapija i biblioterapijske individualne konzultacije) uspoređeno je stanje depresije na početku i kraju tretmana. Zanimljivo je bilo otkriti koji od ta dva pristupa (grupni + knjižničar ili individualni + psiholog) u konačnici daje bolje rezultate te može li knjižničar jednako dobro provoditi postupak biblioterapije kao i psiholog. Rezultat je pad razine stresa u obje skupine, s tim da je nešto veći pad zabilježen u konzultacijskoj skupini. Ipak, razlika nije značajna i smatra se da je uvjetovana načinom provođenja, a ne osobama.

Iz ovog istraživanja možemo zaključiti da uloga sveučilišnog knjižničara i sveučilišne knjižnice može biti proširena i na to područje: područje pomoći studentima da se pomoću knjiga i biblioterapijskog postupka bolje snalaze u svijetu problema na koje za vrijeme studiranja nailaze te da takvi, „ohrabreni i ojačani“, budu sposobni postizati i bolje rezultate.

\subsubsection{Uloga sveučilišnog knjižničara}

N. Mikuletič u svom članku Biblioterapija u školskoj knjižnici ili razgovor o knjizi ističe prednost školskih knjižničara pred ostalim stručnim djelatnicima u školi zato što upravo oni upoznaju učenike izvan nastave. Ona smatra da se mladi pred knjižničarom ponašaju prirodnije jer nema pritiska ocjenjivanja, a nerijetko mu se požale i na probleme koji ih muče.$^{30}$ Možemo se zapitati postoji li takva bliskost u odnosu prema knjižničaru i među studentskom populacijom sveučilišnih i visokoškolskih knjižnica. Udaljuje li ozbiljnost akademskog života njegove sudionike i nameće li se u ovom slučaju osjećaj nedostupnosti i nemogućnosti druge vrste razgovora osim razgovora o literaturi i građi potrebnoj za uspješno školovanje? Činjenica je da, koliko god ozbiljni bili i koliko god radili na edukativnosti koja jest osnova postojanja akademskog društva, knjižničari u tim knjižnicama mogu napraviti i puno više. Znameniti austrijski psihijatar i psihoterapeut V. E. Frankl smatra da je svaki suvremeni čovjek, osobito ako je k tomu još i mlad, egzistencijalno frustriran i proganja ga osjećaj besmisla. ${ }^{31} \mathrm{U}$ susretu s nizom životnih i obrazovnih problema s kojima se suvremeni mladi čovjek, student, susreće na putu svog obrazovanja, ljubaznost i prijateljski odnos knjižničara može značiti

30 Usp. Mikuletič, N. Nav. dj., str. 135.

31 Usp. isto. 
jednako koliko i njegova stručna pomoć u pronalaženju i obuci za pronalaženje potrebne građe.

Ukoliko bi se provodila u sveučilišnim knjižnicama, sudeći prema rezultatima prethodno prikazanog istraživanja, biblioterapija bi mogla biti značajna pomoć studentu na putu do cilja: lakši i ljepši životni put, oslobođen stresa, a tako i put koji otvara vrata kvalitetnijem i uspješnijem obrazovanju. Knjižničar koji bi imao afinitet prema toj vrsti rada s korisnicima trebao bi, uz poznavanje problematike sadržane u određenoj literaturi i utjecaja koji određena literatura ima na svoje recipijente, pomalo poznavati i psihologiju studenata, ne zanemarujući pritom i njihova individualna obilježja. Tu se javlja i nova uloga sveučilišnog knjižničara koju možda ne bi mogli ili željeli vršiti svi visokoškolski knjižničari, ali afinitet za tu vrstu pomoći sigurno će naći plodno tlo među određenim knjižničarima te će, ako se poradi na njihovu osposobljavanju i stručnosti te uspostavi suradnja s odjelima i ustanovama unutar i izvan matičnog sveučilišta koje su upućene u provođenje biblioterapije, i sveučilišna knjižnica dobiti dodatnu moralno-obrazovnu dimenziju.

\section{Zaključak}

Pojmovi knjiga i knjižnica kriju brojna značenja i niz mogućnosti koje iz njihove definicije nisu vidljive. Jedna od njih jest i njihova terapijska snaga. Međutim da bi one zaživjele u svojoj terapijskoj ulozi, treba ponajprije postojati svijest o njoj. Budući da se biblioterapija u svojim počecima vezala isključivo uz medicinsko i psihologijsko okružje, mnogi knjižničari još nisu u potpunosti osvijestili brojne mogućnosti koje upravo oni, kao poznavatelji knjiga i ljudi (knjižničnih korisnika), u tom području mogu imati. Istraživanje M. Foresta iz 1998. godine, prikazano u ovom radu, pokazuje da zastupljenost biblioterapije u knjižničarskoj profesiji s vremenom raste te da su knjižničari na tom polju zauzeli visoko drugo mjesto, odmah iza psihologa, a iznad medicinskog osoblja te socijalnih radnika.

Hoće li se biblioterapija provoditi u knjižnicama, ovisi i o vrsti biblioterapije. Institucionalnoj i kliničkoj biblioterapiji nije mjesto u knjižnicama, no u razvojnoj biblioterapiji knjižnice mogu dati velik doprinos. Stupanj provođenja biblioterapije u knjižnicama ovisi također i o vrsti knjižnice. Većina literature koja govori o tom području, a vezana je uz iskustva hrvatskih knjižnica, odnosi se na školske knjižnice te ponešto i na narodne knjižnice. Međutim iskustva nekih svjetskih knjižnica pokazuju kako bi i sveučilišne knjižnice mogle na tom području dati svoj doprinos. Upravo su studenti kategorija mladih ljudi koja je, što zbog zahtjevnog studijskog programa, a što zbog nekih drugih okolnosti kojima su za vrijeme studija izloženi, često izložena stresu. Sveučilišni knjižničar koji bi bio zainteresiran za provođenje biblioterapije trebao bi, uz poznavanje literature i biblioterapijskog postupka, biti upućen i u psihologiju te grupe mladih ljudi, ne zanemarivši pritom ni psihološka obilježja pojedinca. I inače upućen na suradnju sa sveučilišnim odje- 
lima te raznim centrima i ustanovama unutar matičnog sveučilišta i izvan njega, sveučilišni knjižničar pritom može potražiti pomoć psihologa ili mišljenje drugih stručnih osoba koje već imaju iskustva u provođenju biblioterapije, učvršćujući na taj način međusobne odnose i razvijajući međusobnu suradnju. Na taj način sveučilišna knjižnica može dobiti i novu dimenziju kojom se potvrđuje da drevni natpis nad ulazom u starogrčku knjižnicu u Tebi, a prema kojem je knjižnica mjesto za ozdravljenje duša, vrijedi i za ovu vrstu knjižnica.

\section{LITERATURA}

Bašić, I. Biblioterapija i poetska terapija: priručnik za početnike. Zagreb: Balans centar, 2011.

Fanner, D; C. Urquhart. Bibliotherapy for mental health service users Part 1: A systematic review. // Health Information \& Libraries Journal 25, 4(2008), 237-252.

Forrest, M. Recent development in reading therapy: a rewiew of the literature. // Health Library Review 15, 3(1998), 157-164.

Indrasiene, V.; E. Kapočiute. Usage of bibliotherapy elements when solving adolescent socio-pedagogical problems. // Socialinis Ugdymas 18, 7(2009), 87-98. [citirano: 2018-22-11]. Dostupno na http://eds.a.ebscohost.com/eds/pdfviewer/pdfviewer?vid $=13 \&$ sid $=2653 \mathrm{a} 38 \mathrm{~d}-6 \mathrm{ed} 8-4838-9 \mathrm{c} 14-5532 \mathrm{ea} 97 \mathrm{f} 6 \mathrm{a} 7 \% 40$ sessionmgr4008.

Janavičiene, D. Bibliotherapy process and type analysis: review of posibilities to use it in the library. // Tiltai 4(2010), 119-132. [citirano 2018-11-12]. Dostupno na: http://eds.a.ebscohost.com/eds/pdfviewer/pdfviewer?vid=12\&sid=c684bed2-d298-4869-8f78-e9bcb149b414\%40sessionmgr4008.

Kulundžić, Z. Put do knjige. Zagreb : Epoha, 1959.

Krpan, K.; I. Klak Mršić; V. Cej. Primjena razvojne biblioterapije u radu s djecom i mladima u narodnoj knjižnici. // Vjesnik bibliotekara Hrvatske 61, 1(2018), 345-361.

Massey, G. Egipatska knjiga mrtvih. [citirano: 2018-11-22] Dostupno na: http://nikolavujic.weebly.com/uploads/3/4/8/0/3480733/gerald_massey_-_egipatska_knjiga_ mrtvih.pdf.

Mikuletič, N. Biblioterapija u školskoj knjižnici ili razgovor o knjizi. // Vjesnik bibliotekara Hrvatske 53, 2(2010), 133-140.

Muto, T.; S. C. Hayes; T. Jeffcoat. The effectiveness of acceptance and commitment therapy bibliotherapy for enhancing the psychological health of Japanese college students living abroad. // Behavior therapy 42(2011), 323-335. DOI 10.1016/j. beth.2010.08.009. 
Raguotiene, G. Atversta knyga. Vilinus, 2008. [citirano: 2018-22-11]. Dostupno na: http://eds.a.ebscohost.com/eds/pdfviewer/pdfviewer?vid=13\&sid=2653a38d-6ed84838-9c14-5532ea97f6a7\%40sessionmgr4008.

Reščič-Rihar, T.; J. Urbanija. Biblioterapija. Ljubljana: Filozofska fakulteta, Oddelek za bibliotekarstvo, 1999.

Riahinia, N.; A. Asemi. Librarians' participation in bibliotherapy treatment of distressed students. // Interdisciplinary Journal of Contemporary Research in Business 3, 6(2011), 709-721.

Rudež, J. Bibliografska metodologija. // Hrvatski 2, 1-2(2004), 55-82.

Rudež, J. Biblioterapija. // Hrvatski 3, 1-2(2005), 99-132.

Stipčević, A. Sudbina knjige. Lokve: Naklada Benja, 2000.

Sučylaite, J. Interakcine biblioterapija medicinoje. // Gydymo menas 1(2004), 86-87.

Šurlan, D. Biblioterapija. // Godišnjak knjižničarskog društva Sisačko-moslavačke županije 2(2008), 13-14.

Škrbina D. Art terapija i kreativnost. Zagreb: Veble commerce, 2013.

Velagić, Z. Povijesnost koncepcije knjižničnog trećeg prostora. // Narodne knjižnice kao treći prostor: zbornik radova / 9. savjetovanje za narodne knjižnice u Republici Hrvatskoj; uredile Dunja Marija Gabriel i Jelica Leščić. Zagreb: Nacionalna i sveučilišna knjižnica, 2015. Str. 29-42. 